\section{ORANGE-BELLIED HIMALAYAN SQUIRREL DREMOMYS LOKRIAH IN LAWACHARA NATIONAL PARK, BANGLADESH}

\section{P.O. Nameer ${ }^{1}$, Petra Österberg ${ }^{2}$ and Mohammed Shahriar Mahmud ${ }^{3}$}

${ }^{1}$ Assistant Professor, Department of Wildlife Sciences, College of Forestry, Kerala Agricultural University, Thrissur, Kerala, India 2 Oxford-Brookes University, Headington Campus, Gipsy Lane, Oxford, United Kingdom

${ }^{3}$ Asiatic Society of Bangladesh, Dhaka, Bangladesh

Email: ${ }^{1}$ nameer.ommer@gmail.com, ${ }^{2}$ posterbe@hotmail.com

plus web supplement of 1 page

Orange-bellied Himalayan Squirrel Dremomys lokriah (Hodgson, 1836) is a medium sized forest squirrel with a head to body length of $200 \mathrm{~mm}$ and tail length of $220 \mathrm{~mm}$. The dorsal coat is dark rufous brown speckled with yellowishbrown, while the ventral side is orange, varying from pale to rusty red (Prater, 1971; Menon, 2003).

Orange-bellied Himalayan Squirrel Dremomys lokriah is distributed from central Nepal east to Salween river, Tibet (China), northern Myanmar, Bhutan and mountains of eastern India (Prater, 1971; Corbet \& Hill, 1992; Hoffmann et al., 1993; Menon, 2003). Reza Khan's (1982; 1985) publications on 'Bangladesh Mammals' do not mention the Orange-bellied Himalayan Squirrel Dremomys lokriah in Bangladesh. However, a very recent publication on the Status of South Asian Nonvolant Small Mammals by Molur et al. (2005) gives the global distribution of the species as Bangladesh, Bhutan, China, India, Myanmar and Nepal. This is based on a single sighting of the species by Sanjay Molur in 2002 from Lawachara National Park in Bangladesh.

On 1 June 2006 during the course of a study visit to Lawachara National Park $\left(24^{\circ} 19.7^{\prime} \mathrm{N}-91^{\circ} 47.2^{\prime} \mathrm{E}\right)$ (Fig. 1) at an altitude of $46 \mathrm{~m}$ we sighted two individuals of Orange-bellied Himalayan Squirrel Dremomys lokriah (Image $2^{\mathrm{w}}$ ). The habitat is tropical evergreen or semievergreen forest, consisting of natural and planted tree species in an old natural forest area. Dominant tree species are Dipterocarpus turbinatus, Artocarpus spp., Tectona grandis, Dillenia pentagyna etc. (Nishorgo Support Project, 2006). During a Hoolock Gibbon census between May and July the second author regularly sighted Drenomys lokriah throughout Lawachara in areas with mixed tall vegetation.

The present sighting is of significance since it confirms beyond doubt and with photograph the earlier record by Molur et al. (2005). The Orange-bellied Himalayan Squirrel is a Near Threatened species in South Asia based on the IUCN Red List Criteria and Categories (Version 3.1) and the IUCN Red List Regional Guidelines (Version 3.0) according to Conservation Assessment Management Plan Workshop (Molur et al., 2005). This status has been arrived at taking into account the restricted extent of occurrence and area of occupancy within Bangladesh, with major threats affecting habitat area and quality in Bangladesh. However, the national status of this species for Bangladesh is downlisted from Vulnerable $($ B 1ab(iii) $+2 a b(i i i))$ to Near Threatened since it is found in the

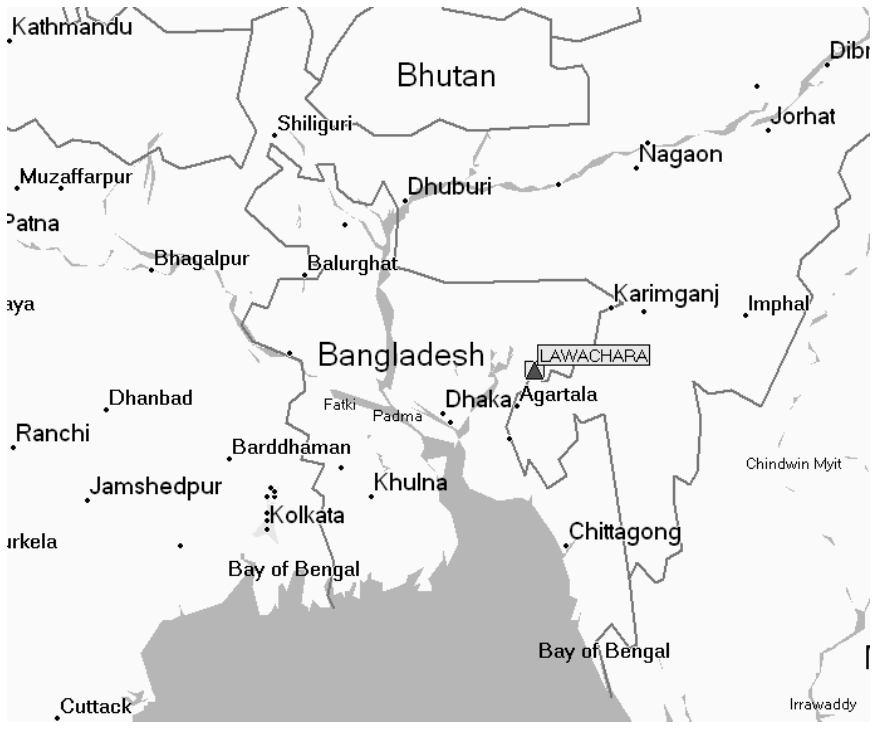

Figure 1. Location of Lawachara National Park, Bangladesh

neighbouring parts of India with the situation slightly better and because of the possibility of recolonization.

\section{REFERENCES}

Corbet, G.B. \& J.E. Hill (1992). The Mammals of the Indomalayan Region: A Systematic Review. Oxford University Press, Oxford, 488pp.

Hoffmann, R.S., C.G. Anderson, R.W. Thorington Jr. \& L.R. Heaney (1993). Family: Sciuridae, pp.419-465. In: Wilson, D.E. and D.M. Reeder (eds.). Mammal Species of The World: A Taxonomic and Geographic Reference. Smithsonian Institution Press. Washington, D.C., 1206pp.

Khan, M.A.R. (1982). Wildlife of Bangladesh - A Checklist. Dhaka University, Dhaka, Bangladesh, 174pp+iv.

Khan, M.A.R. (1985). Mammals of Bangladesh - A Field Guide. Dhaka, Bangladesh, $91 \mathrm{pp}$.

Menon, V. (2003). A Field Guide to Indian Mammals. Dorling Kindersley (India), Pvt. Limited, 201pp.

Molur, S, C. Srinivasulu, B. Srinivasulu, S. Walker, P.O. Nameer \& L. Ravikumar (2005). Status of South Asian Non-volant Small Mammals: Conservation Assessment and Management Plan (C.A.M.P.) Workshop Report. Zoo Outreach Organisation/CBSG-South Asia, Coimbatore, India, $618 \mathrm{pp}$.

Nishorgo Support Project (2006). Management plans for Lawachara National Park. Nishorgo Support Project, Forest Department, Ministry of Environment and Forests, Government of Bangladesh, Dhaka, 155pp. http://www.nishorgo.org/reference_center.asp (accessed on 8 June 2006) Prater, S.H. (1971). The Book of Indian Animals. Oxford University Press, Bombay, 324pp.

\section{Acknowledgement}

We thank Prof. Anwar-ul-Islam and Ms. Sally Walker for making this trip to Lawachara National Park possible. The first author would like to thank the Vice-Chancellor and Registrar of Kerala Agricultural University and the Associate Dean, College of Forestry, Kerala Agricultural University for permitting him to go to Bangladesh. Our thanks are also due to Asiatic Society of Bangladesh, Govt. of Bangladesh and CIDA. The second author would especially like to thank Prof. Anwar-ul-Islam, the Chief Conservator of Forest, Forest Department of Bangladesh for making it possible to carry out the fieldwork in Lawachara. We also thank Mr. Sirajul Hossain for the photograph of the Orange-bellied Himalayan Squirrel Dremomys lokriah taken in Lawachara National Park.

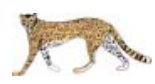

${ }^{\text {w }}$ See Image 1 in the web supplement at www.zoosprint.org 